\title{
Rupture of the mammary vein in a Holstein cow with mastitis and udder edema: case report
}

\author{
Ruptura da veia mamária em vaca da raça Holandês com \\ mastite e edema de úbere: relato de caso
}

\author{
Michel Abdalla Helayeli*, Adriano Tony Ramos², Samara de Paula Lopes³, Isabelle Magalhães da Cunha4, \\ Paulo César Amaral Ribeiro da Silva ${ }^{5}$, Robson Pacheco Rocha Moutinho ${ }^{6}$, Vivian de Assunção Nogueira Carvalho ${ }^{7}$ \\ \& Saulo Andrade Caldas ${ }^{8}$ \\ 'Veterinarian, Dr. Departamento de saúde coletiva veterinária e saúde pública - MSV, Faculdade de Veterinária, Universidade \\ Federal Fluminense - UFF, Niterói, RJ, Brasil \\ Veterinarian, Dr. Faculdade de Medicina Veterinária, Universidade Federal de Santa Catarina - UFSC, Curitibanos, SC, Brasil \\ ${ }^{3}$ Veterinarian, MSc., Doctorate student in Veterinary Medicine. Universidade Federal Rural do Rio de Janeiro - UFRRJ, \\ Seropédica, RJ, Brasil \\ ${ }^{4}$ Veterinarian, MSc., Student in Clinical Sciences and Animal Reproduction. Universidade Federal Fluminense - UFF, Niterói, RJ, \\ Brasil \\ ${ }^{5}$ Veterinarian, Dr. Departamento de Patologia e Clínica Veterinária - MCV, Faculdade de Medicina Veterinária, Universidade \\ Federal Fluminense - UFF, Niterói, RJ, Brasil \\ 'Veterinary medicine student. Universidade Federal Fluminense - UFF, Niterói, RJ, Brasil \\ `Veterinarian, Dr. Seção de Anatomia Patológica - SAP, Departamento de Epidemiologia e Saúde Pública - DESP, Universidade \\ Federal Rural do Rio de Janeiro - UFRRJ, Seropédica, RJ, Brasil \\ §Veterinarian, Professor. Departamento de Medicina e Cirurgia Veterinária - DMCV, Universidade Federal Rural do Rio de \\ Janeiro - UFRRJ, Seropédica, RJ, Brasil
}

\begin{abstract}
The aim of this report was to describe the clinical-pathological data of a case of clinical mastitis in a 20-day postpartum Holstein cow who presented udder edema and rupture of the ventral subcutaneous abdominal vein, and then died. This animal showed an increased volume of the left iliac fossa region, an increase in the size of the udder, and a marked decrease in milk production. Signs of parenchymal inflammation were observed during clinical examination. The screened mug test and California Mastitis Test (CMT) were then performed, and their results were negative. However, Staphylococcus aureus was isolated from milk and liquid collected by puncture from the ventrolateral region of the abdomen. Signs of bleeding and dehydration were found through blood counts and serum biochemistry. Soon after dying, the animal was submitted to necropsy, in which rupture of the mammary vein and intense inflammation with fibrin deposition and detachment of the subcutaneous tissue were observed. Histological examination revealed degeneration, diffuse necrosis, and thrombosis with areas of neovascularization associated with fibrin and cellular debris in the mammary vein.
\end{abstract}

Keywords: mammary gland, infection, bovine.

\section{Resumo}

O objetivo do relato foi descrever os dados clínicos-patológicos de um caso de mastite clínica em uma vaca da raça Holandês com 20 dias de puerpério, que apresentou edema de úbere, ruptura da veia subcutânea ventral abdominal e veio a óbito. Esse animal apresentou aumento de volume na região da fossa ilíaca esquerda, aumento no tamanho do úbere, com acentuada queda na produção de leite. Sinais de inflamação parenquimatosa foram observados durante exame clínico. Então, testes da caneca telada e California Mastitis Test (CMT) foram realizados e seus resultados foram negativos. Foi isolado Staphylococcus aureus do leite e do líquido colhido por meio de punção na região ventro-lateral do abdômen. Sinais de hemorragia e desidratação foram mostrados com a realização de hemograma e bioquímica sérica. Logo após morrer, o animal foi submetido à necropsia na qual foi observado ruptura da veia mamária, intensa inflamação com depósito de fibrina e desprendimento do tecido subcutâneo. Ao exame histológico, verificou-se degeneração, necrose difusa, trombose comáreas de neovascularização associadas a fibrina e restos celulares na veia mamária.

Palavras-chave: glândula mamária, infecção, bovino.
How to cite: Helayel, M. A., Ramos, A. T., Lopes, S. P., Cunha, I. M., Silva, P. C. A. R., Moutinho, R. P. R. Carvalho, V. A. N., \& Caldas, S. A. (2018). Rupture of the mammary vein in a Holstein cow with mastitis and udder edema: case report. Brazilian Journal of Veterinary Medicine, 40, e094118. doi: 10.29374/2527-2179.bjvm094118

\section{Financial support: CNPq.}

Conflict of interests: No conflict of interests declared concerning the publication of this article.

Received: April 05, 2018

Accepted: September 20, 2018

Thestudy was carried out at Hospital Veterinário Universitário da Universidade Federal do Tocantins - HVU-UFT, Araguaina, TO, Brasil.

\section{${ }^{*}$ Correspondence}

Michel Abdalla Helayel

Departamento de saúde coletiva veterinária e saúde pública - MSV, Faculdade de Veterinária, Universidade Federal Fluminense - UFF Rua Vital Brasil, 64, Santa Rosa CEP 24320-340 - Niterói (RJ), Brasil E-mail:michelabdalla@id.uff.br 


\section{Introduction}

Mastitis and udder edema are the most important and frequent mammary gland disorders in milk-producing animals, which cause economic losses to milk producers and the dairy industry worldwide (Tozzetti et al., 2008; Hogeveen et al., 2011; Paul \& Ganguly, 2014; Pereira et al., 2014; Saab et al., 2014; Fogsgaard et al., 2015).

Mastitis is the inflammation of the mammary gland parenchyma. It is a multifactorial disease of multiple etiologies (Vliegher et al., 2012), which is classified as clinical mastitis when there are evident signs of pain, heat, flushing, edema and hardening of the mammary gland, and/or lumps, pus, or any other changes in milk characteristics (Ebrahimi et al., 2014; Royster \& Wagner, 2015). Severe cases can present clinical signs such as fever, anorexia, dehydration, septicemia, and death (Freitas et al., 2005). Subclinical mastitis shows no apparent changes, but there may be damage to the parenchyma of the gland and many modifications of milk components, such as fat, protein, lactose, minerals, electrolytes, and enzymes (Cunha et al., 2008). Microbiological and biochemical techniques are used to identify the biological agents that cause mastitis (Ebrahimi et al., 2014; Royster \& Wagner, 2015).

Bacteria belonging to the genus Staphylococcus are the predominant causes of mastitis in the main milk-producing species in Brazil, and Staphylococcus aureus has a higher prevalence than other species in milk samples from cases of bovine mastitis, both in Brazil and internationally (Saeki et al., 2012; Bandeira et al., 2013; Castelani et al., 2013; Jamali et al., 2014; Acosta et al., 2016). The disease can be hyperacute, although the subclinical and chronic subclinical forms may also present clinical episodes (Quinn et al., 2002; Nader Filho et al., 2007).

Udder edema is characterized by excess fluid in intercellular spaces and has multiple causes, such as circulatory disorders, inheritability, and diet (Schultz, 1978). It occurs in first-calf heifers or in multiparous cows two to three weeks before calving, persisting for up to three weeks after calving without complications. It may also become severe and require immediate clinical intervention (Radostits et al., 2007). According to Carlsen et al. (1969) and Hemken et al. (1969), udder edemas can be classified into five levels, ranging from grade 1 (without edema) to grade 5 (with very severe edema). Tucker et al. (1992) presented a different classification with greater amplitude and more types, ranging from $\mathrm{O}$ (no edema) to 10 (severe edema). We have not found any reports of a mammary vein lesion occurring as a consequence of mastitis or pathological udder edema in the literature.

This report describes the clinical-pathological and laboratory data of a case of mastitis, udder edema, rupture of the subcutaneous abdominal vein, and subsequent death of a Holstein cow treated at the University Veterinary Hospital (HVU) of the School of Veterinary Medicine and Zootechny (EMVZ) of the Federal University of Tocantins (UFT).

\section{Case report}

A multiparous Holstein cow was brought to the HVU-UFT after twenty days of puerperium with a history of increased volume in the udder (on the $4^{\text {th }}$ day postpartum) and left iliac fossa (on the $6^{\text {th }}$ day postpartum) (Figure 1), and hypogalactia. The animal was managed in well-drained Mombasa grass (Panicum maximum) paddocks with good hygienic conditions. Milking was manual, in a room with poor hygiene and without milking management.

The owner reported intramuscular treatment with an intramammary antibiotic suspension containing $200 \mathrm{mg} / \mathrm{kg} /$ day oxytetracycline, $0.01 \mathrm{mg} / \mathrm{kg} /$ day flumetasone, and $0.2 \mathrm{mg} / \mathrm{kg} /$ day trichloromethiazide, associated with $0.01 \mathrm{mg} / \mathrm{kg} /$ day dexamethasone for two days starting on the seventh day of puerperium.

The animal underwent clinical examination according to Dirksen et al. (1993). The observed changes consisted of 10-second capillary refill time (CRT), 15-second skin turgor, severe bilateral enophthalmos (Figure 2), and tachycardia with 120 heartbeats per minute (bpm) but no arrhythmia, characterizing 10 to $12 \%$ dehydration. The apparent mucous membranes were pale, the mammary and iliofemoral lymph nodes presented bilateral lymphadenomegaly, the udder was painful at palpation, temperature was elevated, and there was hyperemia and severe edema with a positive Godet sign. The left iliac fossa region presented increased volume and fluid in the subcutaneous space. The screened mug test and the California Mastitis Test (CMT) were both negative. 


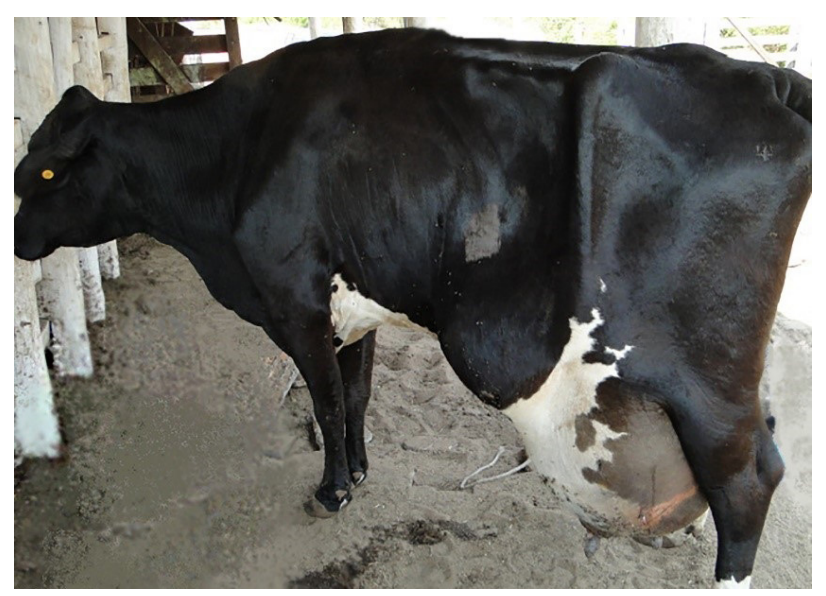

Figure 1. Cow with increased volume of the udder and ventrolateral portion of the left abdomen.

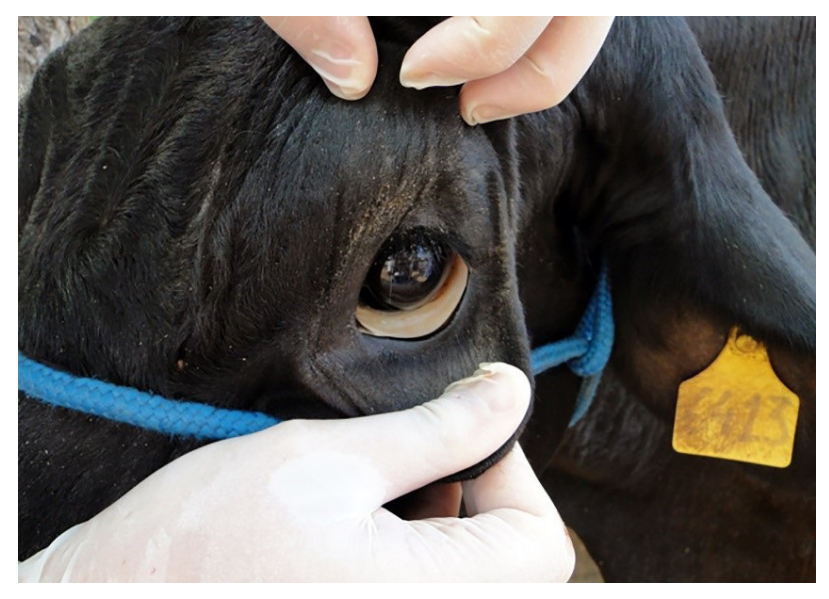

Figure 2. Severe enophthalmos and hypopigmented ocular mucosa.

Blood samples were collected to perform a complete blood count, leukogram, and quantification of the content of total plasma protein (TPP), fibrinogen, urea, and creatinine according to Kaneco et al. (2008).

The blood count showed severe macrocytic hypochromic anemia with anisocytosis, polychromasia, and the presence of reticulocytes, and neutrophil leukocytosis with inversion of the neutrophil/lymphocyte ratio. There was also mild hypoproteinemia and uremia (Table 1).

A composite milk sample of the four quarters was collected in a sterile tube, and fluid from the subcutaneous tissue of the left iliac fossa region was collected through an aspiration puncture using a 40×12-gauge needle according to Dirksen et al. (1993). The milk and fluid samples were subsequently sent to the Laboratory of Hygiene and Public Health of the UFT for culture and microbiological isolation.

The aspirated secretion was serosanguineous, cloudy, and contained $6.2 \mathrm{~g} / \mathrm{dL}$ of total proteins, a large number of erythrocytes in the sediment, and bacteria. Growth of $S$. aureus was seen both in the milk sample and in the edema liquid.

Seventy-five liters of serosanguinous transudate were drained from the left iliac fossa region (Figure 3) through the insertion of a $12 \mathrm{~mm}$ silicone tubular drain using the technique described by Chaffin (1998).

A treatment based on $10 \%$ enrofloxacin ( $1 \mathrm{~mL} / 40 \mathrm{~kg}, \mathrm{IM}, \mathrm{SID}), 2 \%$ meloxicam $(2.5 \mathrm{~mL} / 100 \mathrm{~kg}$, IM, SID), blood transfusion, and replacement and maintenance fluid therapy with Ringer's lactate and 
Table 1. Blood count results and serum biochemistry of a Holstein cow with clinical mastitis, udder edema, and rupture of the mammary vein.

\begin{tabular}{|c|c|c|c|c|c|c|}
\hline Blood count & $\begin{array}{l}\text { Hemat. } \\
5-10 \times 10^{6} / \mu \mathrm{L}\end{array}$ & $\begin{array}{l}\text { Leuk. } \\
4.1-12 \times 10^{3} / \mu \mathrm{L}\end{array}$ & $\begin{array}{c}\mathrm{Hb} \\
8-14 \mathrm{~g} / \mathrm{dl}\end{array}$ & $\underset{26-42 \%}{\mathrm{Ht}}$ & $\begin{array}{c}\text { MCV }^{\mathrm{a}} \\
40-60 f l\end{array}$ & $\begin{array}{l}\mathrm{MCHC}^{\mathrm{a}} \\
30-36 \%\end{array}$ \\
\hline & 1.73 & 14.7 & 3.7 & 14 & 81 & 26 \\
\hline \multirow[t]{2}{*}{ Leukogram } & $\begin{array}{l}\text { Basophils } \\
0 \times 10^{3} / \mu \mathrm{L}\end{array}$ & $\begin{array}{c}\text { Eosinophils } \\
0.1-1.5 \times 10^{3} / \mu \mathrm{L}\end{array}$ & $\begin{array}{c}\text { Segmented } \\
\text { neutrophils } \\
1.5-5 \times 10^{3} / \mu \mathrm{L}\end{array}$ & $\begin{array}{c}\text { Band neutrophils } \\
0-0.19 \times 10^{3} / \mu \mathrm{L}\end{array}$ & $\begin{array}{l}\text { Lymphocytes } \\
3-7.5 \times 10^{3} / \mu \mathrm{L}\end{array}$ & $\begin{array}{c}\text { Monocytes } \\
0.1-1.5 \times 10^{3} / \mu \mathrm{L}\end{array}$ \\
\hline & 00 & 01 & 7.8 & 04 & 5.3 & 0.8 \\
\hline \multirow[t]{2}{*}{ Serum biochemistry } & $\begin{array}{c}\text { Urea } \\
\text { 20-30mg/dL }\end{array}$ & $\begin{array}{l}\text { Creatinine } \\
1-2.0 \mathrm{mg} / \mathrm{dL}\end{array}$ & $\begin{array}{c}\text { TPP } \\
6.7-7.5 g / d L\end{array}$ & $\begin{array}{c}\text { Fibrinogen } \\
200-500 \mathrm{mg} / \mathrm{dL}\end{array}$ & & \\
\hline & 76 & 0.9 & 6.4 & 200 & & \\
\hline
\end{tabular}

aMCV = mean corpuscular volume; MCHC = mean corpuscular hemoglobin concentration; TPP = mean total plasma protein. Source: Jain (1993).



Figure 3. Serosanguineous transudate after drainage of the region around the mammary gland.

glucose solution was immediately started. Despite the suspicion of hemorrhage and the surgical urgency, the clinical situation worsened quickly and the animal died before surgery.

Necropsy revealed about four liters of serosanguineous fluid between the subcutaneous tissue and the abdominal wall of the mammary gland, with fibrin clots next to a clot weighing three kilograms, which was associated with the rupture and thrombosis of the ventral subcutaneous abdominal vein (Figure 4). Fragments of the main organs were collected, fixed in 10\% formalin solution, processed for histopathological evaluation, and treated with hematoxylin and eosin (H\&E) stain. Microscopic examination of the mammary gland showed moderate to severe degeneration, diffuse necrosis, and thrombosis with areas of neovascularization, fibrin, and cellular debris.

\section{Discussion}

The diagnosis of clinical mastitis with udder edema and rupture of the ventral subcutaneous abdominal mammary vein was based on epidemiological data and clinical history associated with necropsy and histological lesions (Fonseca, 2000; Marçal, 2006; Radostits et al., 2007; McGavin, 2009).

Edema formed in the udder may worsen and predispose the udder to trauma, injury, and lesions of the mammary gland and adjacent structures, as well as deterioration of suspensory ligaments and tissues (Vestweber \& Al-Ani, 1983), which may cause complications and progress to agalactia (Prabhakar et al., 1991). This occurred in the present case, where the edema caused 


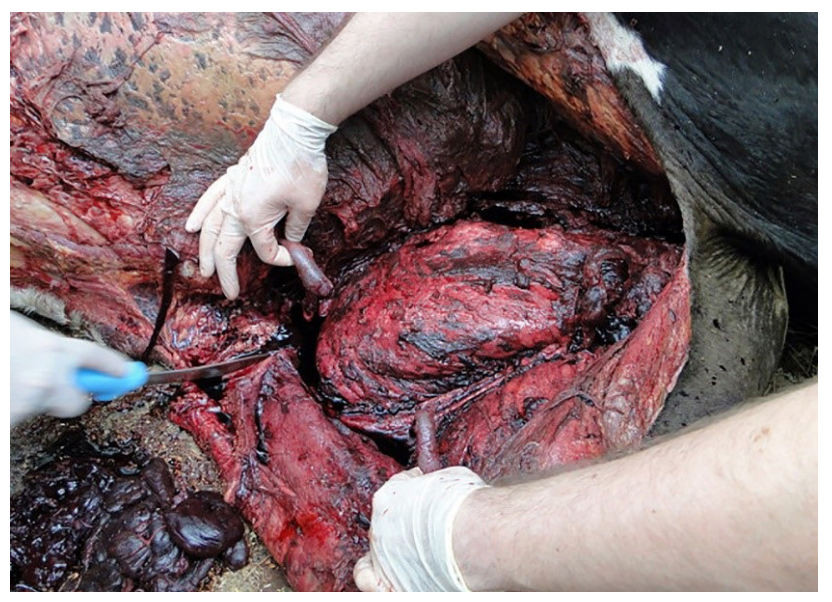

Figure 4. Clots in the mammary gland and rupture of the mammary vein.

by mammary gland inflammation led to relaxation of the udder suspensory ligaments, agalactia, and rupture of the ventral subcutaneous abdominal mammary vein. Bacterial infection can cause reduced venous blood flow and endothelial damage with thrombosis (McGavin, 2009), and when it occurs in a large vein it can cause venous hypertension, passive congestion with edema, and pain in the affected structure (McGuirk et al., 1993). Schmid et al. (2011) mentioned five cases of rupture of the ventral subcutaneous abdominal mammary vein in cows treated at the Zurich Veterinary Hospital. Four of these cows underwent surgical correction immediately after diagnosis and were cured, so only one cow died due to delayed treatment. All of the cows mentioned in that study had suffered some trauma with pointed materials that caused the rupture of the mammary vein, which differed from the present report, in which the farmer did not report any trauma, insect bite, or intravenous drug application. In this case, the development of clinical mastitis and the edema formed were the causes of the rupture. No reports of similar cases caused by clinical mastitis exist in the literature. Even though it is not possible to establish the chronological order of pathophysiological events in this case, the processes described above could explain the rupture of the ventral subcutaneous abdominal mammary vein, extensive edema, and anemia caused by hemorrhage.

In cases where there is a mammary venous lesion, especially in highly milk-producing cows, it is necessary to stop the bleeding quickly due to there being large-caliber vessels irrigating the mammary gland, damage to which can lead to great blood loss in a short period of time. The animal should thus be diagnosed and operated on as soon as possible. All of the cows mentioned by Schmid et al. (2011) suffered skin, subcutaneous tissue, and vein damage, and therefore the extravasation of blood was visible. These cases thus differed from the present report, wherein the cow did not present skin and subcutaneous lesions and the extravasation of blood was subcutaneous and concentrated in the left iliac fossa region and in the udder. This increased the udder size/weight even more and made the correct diagnosis difficult.

The CMT and screened mug test are considered tests of medium specificity and sensitivity (Brito et al., 1997; Ribeiro et al., 2003), so a negative result does not exclude mastitis, since epidemiological and histopathological findings and the clinical signs confirmed the mammary gland inflammation. In addition, tests may be influenced by different factors, such as the infectiousness of the pathogen (Reis et al., 2011), period of the year, breed, lactation stage, production volume, number of lactations, and nutritional problems (Sharma et al., 2011). Staphylococcus aureus is one of the main etiological agents of subclinical, chronic, or clinical mastitis, and sometimes causes gangrenous cases that can lead to the death of the animal. It lives in the udder, upper and lower urogenital tract, and upper respiratory tract of animals, and also on the milker's hands; this bacterium was also isolated in the milk samples and in the serosanguinous fluid collected herein. This microorganism has been frequently identified in mammary quarters as causing mastitis in the immediate postpartum period, especially where correct hygiene practices are 
not carried out during milking and in highly contaminated environments (Radostits et al., 2007; Saeki et al., 2012; Bandeira et al., 2013; Castelani et al., 2013; Jamali et al., 2014; Acosta et al., 2016). S. aureus is among the most important Staphylococcus species that causes mastitis. It produces many virulence factors, such as enterotoxins, coagulase, hemolysin, hyaluronidase, leucocidins, and alpha, beta, and delta toxins, which may be involved in varying degrees of inflammation ranging from subclinical to gangrenous mastitis in postpartum cows (Radostits et al., 2007; Ladeira, 2007; Acosta et al., 2016; Morcuende, 2016). In the present study, it was reported that the proper disinfection of the milking room and quarters was not performed before milking, which probably led to the introduction of bacteria into the parenchyma, causing inflammation and affecting the animal's vital signs.

Hematologic changes reveal acute and severe regenerative anemia, with severe losses of whole blood and partial reuse of substrates. This was confirmed later in the reported case, as the animal had internal or cavitary hemorrhaging (Meyer et al., 1995; Lopes et al., 2007). The leukogram suggested an inflammatory/infectious non-acute process, since there was no increased fibrinogenemia and/or nuclear left-shifted neutrophils (Kaneco et al., 2008; Radostits et al., 2007). This may be because $S$. aureus can cause long-term infections that tend to become chronic, with low cure rates and great milk production losses (Sabour et al., 2004).

The liquid drained from the animal was a characteristic septic exudate. This corroborates the results of Lopes et al. (2007), who described contents of several colors, including red, in similar cases with total protein higher than $3 \mathrm{~g} / \mathrm{dL}$, the presence of bacterial agents, and also erythrocytes due to the diffuse or local inflammatory/infectious reaction that led to increased vascular permeability and vein rupture (De May, 1996; Meyer \& Harvey, 1998).

Both the treatments attempted at the farm and at the HVU in this case agreed with the literature (Carlsen et al., 1969; Mitchell et al., 1976; Vestweber \& Al-Ani, 1983; Janeski et al., 1988; Marçal, 1991; Gilbert \& Schwark, 1992; Radostits et al., 2007), although the response was not satisfactory. Although the sensitivity of $S$. aureus to antimicrobial substances is quite variable, Oliveira et al. (2011) reported that this bacterium is 93.3\% sensitive to enrofloxacin. In contrast, cure rates rarely exceed $50 \%$ and infections generally persist throughout the cow's lifetime (Radostits et al., 2007).

In addition to the diagnosis of mastitis and the presence of extensive edema, clinical and hematological signs led to the suspicion of a hemorrhagic condition, which in postpartum cows usually occurs due to lacerations in the birth canal, retained placenta, uterine inversion, coagulation disorders, and uterine atony (Anderson \& Etches, 2007). Necropsy confirmed the hemorrhagic condition of the animal being due to rupture of the mammary vein, which has not previously been reported as a complication of clinical mastitis or pathological edema in cows.

Mastitis caused by $S$. aureus may occasionally progress to hyperacute mastitis with gangrene, which usually occurs at the beginning of lactation. Disease onset is abrupt, with high fever, profound prostration, and anorexia. The affected quarter is initially inflamed, painful, and has an altered color. Subsequently, it presents gangrenous and necrotic areas produced by venous thrombosis, with local edema and congestion of the udder that progresses to tissue necrosis (Morcuende, 2016). These findings are similar to the case described in this report.

Histological examination showed signs of thrombosis, which may be formed by endothelial lesions from vascular inflammation caused by infectious agents, including bacteria, leading to circulatory disorders, such as venous hypertension, infarction or passive congestion, emboli, edema, and pain, which form conducive media for bacterial development (McGuirk et al., 1993; Mosier, 2009). Blood channels within the thrombus (channeled thrombus) were also observed under microscopy, representing an attempt by the organism to restore circulation (De May, 1996; Meyer \& Harvey, 1998), which confirms the occurrence of mastitis in this case.

\section{Conclusion}

As the lesion reported herein is not well-described in the literature and manifested severe signs that caused the patient's death due to large vein lesions and extensive blood loss, this report is extremely important to bovine medicine. It also provides more information on possible complications in cases of mastitis with parenchymatous inflammation and severe edema, such as the involvement (laceration) of the suspensory ligaments of the udder due to the excess 
weight present in these cases, which can result in detachment of the mammary gland with vessel rupture. The vascular lesions then formed (showing inflammation, degeneration, and increased permeability) can lead to the rupture of the vessels that are part of or around the udder.

\section{References}

Acosta, T. C., Silva, L. B. G., Medeiros, E. S., Pinheiro-Júnior, J. W., \& Mota, R. A. (2016). Mastites em ruminantes no Brasil. Pesquisa Veterinária Brasileira, 36(7), 565-573. http://dx.doi.org/10.1590/s0100-736X2016000700001.

Anderson, J. M., \& Etches, D. (2007). Prevention and management of postpartum hemorrhage. American Family Physician, 75(6), 875-882. PMid:17390600.

Bandeira, F. S., Picoli, T., Zani, J. L., Silva, W. P., \& Fischer, G. (2013). Frequency of Staphylococcus aureus from bovine subclinical mastitis cases, in southern Rio Grande do Sul, Brazil. Arquivos do Instituto Biológico, 80(1) 1-6. http://dx.doi.org/10.1590/S1808-16572013000100001.

Brito, J. R. F., Caldeira, G. A. V., Verneque, R. S., \& Brito, M. A. V. P. (1997). Sensibilidade e especificidade do "California Mastitis Test" como recurso diagnóstico da mastite subclínica em relação à contagem de células somáticas. Pesquisa Veterinária Brasileira, 17(2), 49-53. http://dx.doi.org/10.1590/50100-736X1997000200002.

Carlsen, H. E., Keith, J. M., \& Croshae, J. E. (1969). Effect of trichlormethiazide and dexametasone on control of udder edema and milk production in lactating dairy cows. Journal of Dairy Science, 52(2), 281.

Castelani, L., Santos, A. F. S., Santos Miranda, M., Zafalon, L. F., Pozzi, C. R., \& Arcaro, J. R. P. (2013). Molecular typing of mastitis-causing Staphylococcus aureus isolated from heifers and cows. International Journal of Molecular Sciences, 14(2), 4326-4333. http://dx.doi.org/10.3390/ijms14024326. PMid:23429273.

Chaffin, M. K. (1998). Thoracocentesis and pleural drainage in horses. Equine Veterinary Education, 10(2), 106108. http://dx.doi.org/10.1111/j.2042-3292.1999.tb00929.x.

Cunha, R. P. L., Molina, L. R., Carvalho, A. U., Facury Filho, E. J., Ferreira, P. M., \& Gentilini, M. B. (2008). Mastite subclínica e relação da contagem de células somáticas com número de lactações, produção e composição química do leite em vacas da raça Holandesa. Arquivo Brasileiro de Medicina Veterinária e Zootecnia, 60(1), 19-24. http://dx.doi.org/10.1590/S0102-09352008000100003.

De May, R. (1996). The art and science of cytopathology (Vol.1-2). Chicago: American Society of Clinical Pathologists.

Dirksen, G., Gründer, H. D., \& Stöber, M. (1993). Rosenberger, exame clínico dos bovinos (3rd ed.). Rio de Janeiro: Guanabara-Koogan.

Ebrahimi, A., Soleimani, F., Moatamedi, A., Shams, N., \& Lotfalian, S. (2014). Study on some characteristics of Staphylococci isolated from sheep sub clinical mastitis milk in Shahrekord, Iran. Biological Journal of Microorganism, 2, 57-62.

Fogsgaard, K. K., Bennedsgaard, T. W., \& Herskin, M. S. (2015). Behavioral changes in freestall housed dairy cows with naturally occurring clinical mastitis. Journal of Dairy Science, 98(3), 1730-1738. http://dx.doi.org/10.3168/ jds.2014-8347. PMid:25547306.

Fonseca, L. F. L. (2000). Mastite. In L. F. L. Fonseca \& M. V. Santos (Eds.), Qualidade do leite e controle da mastite São Paulo: Lemos Editorial.

Freitas, M. F. L., Pinheiro-Júnior, J. W., Stamford, T. L. M., Rabelo, S. D. A., Silva, D. D., Silveira Filho, V. D., \& Mota, R. A. (2005). Perfil de sensibilidade antimicrobiana in vitro de Staphylococcus coagulase positivos isolados de leite de vacas com mastite no agreste do estado de Pernambuco. Arquivos do Instituto Biológico, 72, 171-177.

Gilbert, R. O., \& Schwark, W. S. (1992). Udder edema. The Veterinary Clinics of North America, Philadelphia, 8(1), 35-37.

Hemken, R. W., Choate, W. H., \& Plowman, R. D. (1969). Salt and water intake as related to udder edema. Journal of Animal Science, 28, 874.

Hogeveen, H., Huijps, K., \& Lam, T. J. G. M. (2011). Economic aspects of mastitis: new developments. New Zealand Veterinary Journal, 59(1), 16-23. http://dx.doi.org/10.1080/00480169.2011.547165. PMid:21328153.

Jain, N. C. (1993). Essentials of veterinary hematology. Philadelphia: Lea \& Febinger. 417 p.

Jamali, H., Radmehr, B., \& Ismail, S. (2014). Prevalence and antibiotic resistance of Staphylococcus aureus isolated from bovine clinical mastitis. Journal of Dairy Science, 97(4), 2226-2230. http://dx.doi.org/10.3168/jds.20137509. PMid:24534509.

Janeski, K., Crcev, D., \& Panoski, S. (1988). Prilog terapiji edema vimena krava i ovaca (treatment of edema of the udder in cows and sheep). Veterinarski Glasnik, 42, 509-514.

Kaneco, J. J., Harvey, J. W., \& Bruss, M. L. (2008). Clinical biochemistry of domestic animal (6th ed.). Burlington: Academic Press.

Ladeira, S. R. L. (2007). Mastite bovina. In F. Riet-Correa, A. L. Schild, R. A. A. Lemos, \& J. R. J. Borges (Eds.), Doenças de ruminantes e equídeos (3rd ed., Vol. 1, pp. 359-372). Santa Maria: Pallotti.

Lopes, S. T., Biondo, A. W., \& Santos, A. P. (2007). Manual de patologia clínica veterinária (3rd ed.). Santa Maria: Departamento de Clínica de Pequenos Animais, UFSM.

Marçal, W. S. (1991, 22 de abril). Pesquisadores desconhecem as causas do edema de mama nas raças leiteiras. O Estado de São Paulo. Suplemento Agrícola. 
Marçal, W. S. (2006). O edema de mama em bovinos leiteiros. Semina: Ciências Agrárias, 27(1), 115-124. http:// dx.doi.org/10.5433/1679-0359.2006v27n1p115.

McGavin, D. (2009). Bases da patologia em veterinária (4th ed.). Rio de Janeiro: Elsevier.

McGuirk, S. M., Shaftoe, S., \& Lunn, D. P. (1993). Moléstias do sistema cardiovascular. In B. P. Smith (Ed.), Tratado de medicina interna de grandes animais (pp. 467-500). São Paulo: Manole.

Meyer, D. J., \& Harvey, D. J. (1998). Veterinary laboratory medicine: interpretation \& diagnosis. Philadelphia: W. B. Saunders.

Meyer, D. J., Coles, E. H., \& Rich, L. J. (1995). Medicina de laboratório veterinário: interpretação e diagnóstico. São Paulo: Roca.

Mitchell, R. G., Mather, R. E., Swallow, W. H., \& Randy, H. A. (1976). Effects of a corticosteroid and diuretic agent on udder edema and milk-yield in dairy-cows. Journal of Dairy Science, 59(1), 109-112. http://dx.doi.org/10.3168/ jds.S0022-0302(76)84164-1. PMid:1249275.

Morcuende, J. R. (2016). Mastites hiperagudas: manual de tratamento da mastite bovina (Publicações Ciência \& Vida). Bayer Saúde Animal.

Mosier, D. A. (2009). Desordens vasculares e trombose. In M. D. McGavin \& J. F. Zachary (Eds.), Bases da patologia em veterinária (4th ed., pp. 63-100). Rio de Janeiro: Mosby Elsevier.

Nader Filho, A., Ferreira, L. M., Amaral, L. A., Rossi Junior, O. D., \& Oliveira, R. P. (2007). Sensibilidade antimicrobiana dos Staphylococcus aureus isolados no leite de vacas com mastite. Arquivos do Instituto Biológico. Jaboticabal, 74(1), 1-4.

Oliveira, C. M. C., Sousa, M. G. S., Silva, N. S., Mendonça, C. L., Silveira, J. A. S., Oaigen, R. P., Andrade, S. J. T., \& Barbosa, J. D. (2011). Prevalência e etiologia da mastite bovina na bacia leiteira de Rondon do Pará, estado do Pará. Pesquisa Veterinária Brasileira, 31(2), 104-110. http://dx.doi.org/10.1590/S0100-736X2011000200002.

Paul, I., \& Ganguly, S. (2014). Bovine mastitis, an economically important bacterial infection of udder in cattle: a review. Indian Journal of Scientific Research and Technology, 2, 1-2.

Pereira, P. F. V., Stotzer, E. S., Pretto-Giordano, L. G., Müller, E. E., \& Lisbôa, J. A. (2014). Risk factors, etiology and clinical aspects of mastitis in meat ewes of Paraná, Brazil. Pesquisa Veterinária Brasileira, 34(1), 1-10. http:// dx.doi.org/10.1590/S0100-736X2014000100001.

Prabhakar, S. K., Singh, K. B., Singh, R. P., Kehra, S. S., \& Bansal, B. K. (1991). An unusual case of udder edema leading to agalactia. The Indian Veterinary Journal, 68, 577-578.

Quinn, P. J., Markey, B. K., Carter, M. E., Donnelly, W. J., \& Leonard, F. C. (2002). Bacterial causes of bovine mastitis. In P. J. Quinn, B. K. Markey, F. C. Leonard, P. Hartigan, S. Fanning \& E. S. Fitzpatrick (Eds.), Veterinary microbiology and microbial disease (pp. 465-475). Oxford: Blackwell.

Radostits, O. M., Gay, C. C., Hinchcliff, K. W., \& Constable, P. D. (2007). Veterninary medicine: a textbook of the diseases of cattle, sheep, goats, pigs and horses (10th ed.). Philadelphia: Elsevier.

Reis, C. B., Barreiro, J. R., Moreno, J. F., Porcionato, M. A., \& Santos, M. V. (2011). Evaluation of somatic cell count thresholds to detect subclinical mastitis in Gyr cows. Journal of Dairy Science, 94(9), 4406-4412. http://dx.doi. org/10.3168/jds.2010-3776. PMid:21854914.

Ribeiro, M. E. R., Petrini, L. A., Aita, M. F., Balbinotti, M., Stumpf Júnior, W., Gomes, J. F., Schramm, R. C., Martins, P. R., \& Barbosa, R. S. (2003). Relação entre mastite clínica, subclínica infecciosa e não infecciosa em unidades de produção leiteiras na região sul do Rio Grande do Sul. Revista Brasileira de Agrociência, 9, 287-290.

Royster, E., \& Wagner, S. (2015). Treatment of mastitis in cattle. Veterinary Clinics: Food Animal Practice, 31(1), 17-46, v. PMid:25705024.

Saab, A. B., Zamprogna, T. O., Lucas, T. M., Martini, K. C., Mello, P. L., Silva, A. V., \& Martins, L. A. (2014). Prevalence and etiology of bovine mastitis in the Nova Tebas, Parana. Semina: Ciências Agrárias, 35, 835-843. http://dx.doi. org/10.5433/1679-0359.2014v35n2p835.

Sabour, P. M., Gill, J. J., Lepp, D., Pacan, J. C., Ahmed, R., Dingwell, R., \& Leslie, K. (2004). Molecular typing and distribution of Staphylococcus aureus isolates in Eastern Canadian dairy herds. Journal of Clinical Microbiology, 42(8), 3449-3455. http://dx.doi.org/10.1128/JCM.42.8.3449-3455.2004. PMid:15297482.

Saeki, E. K., Peixoto, E. C. T. M., Matsumoto, L. S., Marcusso, P. F., \& Monteiro, R. M. (2012). Mastite bovina por Staphylococcus aureus: sensibilidade às drogas antimicrobianas e ao extrato alcoólico de própolis. Acta Veterinaria Brasilica, 5(3), 284-290. http://dx.doi.org/10.21708/avb.2011.5.3.2172.

Schmid, B., Muggli, E., Schmid, T., \& Nuss, K. (2011). Lebensbedrohliche verletzungen der bauchwandvenen bei milchkühen. Schweizer Archiv fur Tierheilkunde, 153(5), 231-235. http://dx.doi.org/10.1024/0036-7281/ a000187. PMid:21541912.

Schultz, L. H. (1978). Metabolic disorders in dairy cattle. In C. J. Wilcox, H. H. Vavhorn \& B. Harris (Eds.), Large dairy herd management (pp. 393-395). Gainesville: University of Florida.

Sharma, N., Singh, N., \& Bhadwal, M. (2011). Relationship of somatic cell count and mastitis: An overview. AsianAust. Journal of Animal Science, 24, 429-438.

Tozzetti, D. S., Bataier, M. N., \& Almeida, L. R. (2008). Prevenção, controle e tratamento das mastites bovinas: revisão de literatura. Revista Científica Eletrônica de Medicina Veterinária, 7, 1-7. 
Tucker, W. B., Adams, G. D., Lema, M., Aslam, M., Shin, I. S., Leruyet, P., \& Weeks, D. L. (1992). Evaluation of a system for rating edema in dairy cattle. Journal of Dairy Science, 75(9), 2382-2387. http://dx.doi.org/10.3168/ jds.S0022-0302(92)77999-5. PMid:1452844.

Vestweber, J. G. E., \& Al-Ani, F. K. (1983). Udder edema in cattle. The Compendium on Continuing Education for the Practicing Veterinarian, 5, 85.

Vliegher, S., Fox, L. K., Piepers, S., McDougall, S., \& Barkema, H. W. (2012). Mastitis in dairy heifers: nature of the disease, potential impact, prevention, and control. Journal of Dairy Science, 95(3), 1025-1040. http://dx.doi. org/10.3168/jds.2010-4074. PMid:22365187. 